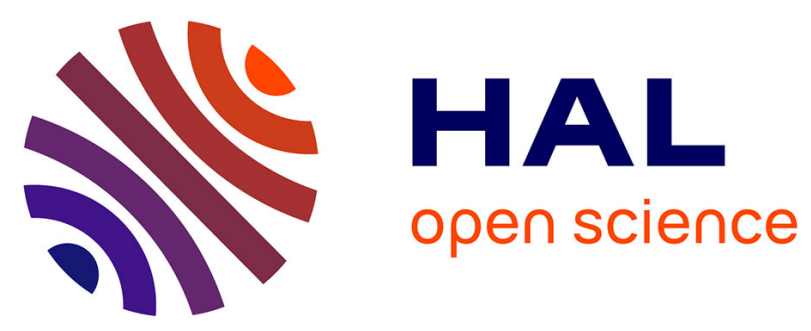

\title{
Utilization of tannin-containing and tannin-free faba beans (Vicia faba) by young chicks : effects of pelleting feeds on energy, protein and starch digestibility
}

\author{
L. Lacassagne, M. Francesch, Bernard B. Carré, J.P. Melcion
}

\section{- To cite this version:}

L. Lacassagne, M. Francesch, Bernard B. Carré, J.P. Melcion. Utilization of tannin-containing and tannin-free faba beans (Vicia faba) by young chicks: effects of pelleting feeds on energy, protein and starch digestibility. Animal Feed Science and Technology, 1988, 2 O (1), pp.59-68. hal-02726341

\section{HAL Id: hal-02726341 \\ https://hal.inrae.fr/hal-02726341}

Submitted on 2 Jun 2020

HAL is a multi-disciplinary open access archive for the deposit and dissemination of scientific research documents, whether they are published or not. The documents may come from teaching and research institutions in France or abroad, or from public or private research centers.
L'archive ouverte pluridisciplinaire HAL, est destinée au dépôt et à la diffusion de documents scientifiques de niveau recherche, publiés ou non, émanant des établissements d'enseignement et de recherche français ou étrangers, des laboratoires publics ou privés. 


\title{
Utilization of Tannin-containing and Tannin-free Faba Beans ( Vicia faba) by Young Chicks: Effects of Pelleting Feeds on Energy, Protein and Starch Digestibility
}

\author{
L. LACASSAGNE ${ }^{1}$, M. FRANCESCH ${ }^{2}$, B. CARRE ${ }^{1}$ and J.P. MELCION ${ }^{3}$ \\ ${ }^{1}$ Institut National de la Recherche Agronomique, Station de Recherches Avicoles, Nouzilly, \\ 37380 Monnaie (France) \\ ${ }^{2}$ Institut de Recerca $i$ Technologia Agroalimentaria, Camb, Apartado 415, Reus, Tarragona \\ (Spain) \\ ${ }^{3}$ Institut National de la Recherche Agronomique, Laboratoire de Technologie des Aliments des \\ Animaux, Rue de la Géraudière, 44072 Nantes Cedex (France)
}

(Received 30 October 1986; accepted for publication 15 September 1987)

\begin{abstract}
Lacassagne, L., Francesch, M., Carré, B. and Melcion, J.P., 1988. Utilization of tannin-containing and tannin-free faba beans (Vicia faba) by young chicks: effects of pelleting feeds on energy, protein and starch digestibility. Anim. Feed Sci. Technol., 20: 59-68.

The nutritive value of the beans of a tannin-free cultivar of Vicia faba was compared with that of beans from 2 tannin-containing cultivars. Experimental diets containing $48 \%$ faba bean were given to 3-week-old chicks, either as pellets or as unpelleted ground feed. Protein from the tanninfree cultivar was more digestible $(82.6 \%)$ than protein from the tannin-containing cultivars $(68.2 \%)$, but starch from the tannin-containing cultivars was more digestible (84.5\%) than starch from the tannin-free cultivar $(75.1 \%)$. Pelleting the diets improved the digestibility of both protein and starch in all cultivars, the most pronounced effect being observed on starch digestibility $(+10.8 \%)$. The apparent metabolisable energy values, corrected for nitrogen balance (AMEn), of the 3 cultivars of field beans were also improved by pelleting. The mean value of the increase in AMEn values owing to pelleting ( $1.23 \mathrm{MJ} \mathrm{kg}^{-1} \mathrm{DM}$ ) represented $12 \%$ of the AMEn value of unpelleted field beans. Regrinding after pelleting did not change the effects of pelleting.
\end{abstract}

\section{INTRODUCTION}

Heat treatment improves the utilization of faba bean seeds by young chicks and adult cockerels (Marquardt and Campbell, 1973, 1974; Marquardt et al., 1974; Huyghebaert and de Groote, 1979, 1980; Huyghebaert et al., 1979; Marquardt and Ward, 1979, 1984).

Previous studies (Edwards and Duthie, 1973; Guillaume, 1974; McNab and 
Wilson, 1974; Shannon and Clandinin, 1977; Guillaume, 1978; Bhargava and O'Neil, 1979) have shown that the heat treatment of field bean seeds results in a $7-15 \%$ increase in their apparent metabolisable energy (AME) value as measured in young birds; the extent of this effect depends in part on the cultivars tested (Guillaume, 1978).

The beneficial effect of heat treatment has been attributed to heat denaturation of trypsin inhibitors, haemagglutinins (Marquardt et al., 1974), antinicotinamide factors (Guillaume, 1974) and tannins (Guillaume and Gomez, 1977; Marquardt and Ward, 1979), which increases the utilization of dry matter (DM), nitrogen, ether-extractable compounds and minerals (Guillaume and Gomez, 1977; Guillaume, 1978; McNab and Wilson, 1974; Marquardt and Ward, 1979).

It is probable that the in vivo digestibility of faba bean starch is also affected by heat treatment. However, only Guillaume (1978) has reported such effects, and confirmation of this finding is required.

The treatments used by the above mentioned authors were: (1) autoclaving (Edwards and Duthie, 1973; Marquardt and Campbell, 1973, 1974; Marquardt et al., 1974, 1976; Shannon and Clandinin, 1977; Guillaume, 1978; Bhargava and O'Neil, 1979; Marquardt and Ward, 1979, 1984); (2) micronising (McNab and Wilson, 1974; Marquardt et al., 1976); (3) extruding and flocking (Marquardt et al., 1976; Huyghebaert and de Groote, 1979, 1980; (4) pelleting of seeds before their inclusion in whole diets (Guillaume, 1974; Marquardt et al., 1976; Huyghebaert and de Groote, 1979); and (5) pelleting of mash after inclusion of faba beans seeds (Huyghebaert and de Groote, 1980). Only the last treatment corresponds to the technical procedures used in the preparation of commercial poultry feedstuffs. It was therefore decided to test the procedure which is most commonly used in practice, i.e. the inclusion of seeds in a whole diet followed by pelleting of the mixture.

The effects of pelleting on the utilization of field beans by young chicks were studied by measuring starch and protein digestibility and determining AME values corrected for nitrogen retention (AMEn). Interaction of the effects of pelleting and the tannin content of the seeds was investigated by testing 3 field bean cultivars, one of which was tannin-free.

\section{MATERIALS AND METHODS}

Three faba bean cultivars were tested: 2 tannin-containing cultivars which are commonly used in France, (Soravi, a winter cultivar, and Alfred, a spring cultivar); and a tannin-free spring cultivar (Blandine) which has recently been officially registered in France.

The faba bean seeds were ground and mixed with an equal weight of a basal fraction $(0)$, which was composed of ground maize, soya bean meal and DLmethionine. Four experimental diets were then prepared by the addition of 
TABLE I

Composition of experimental field bean diets (\%)

\begin{tabular}{lcccc}
\hline \multirow{2}{*}{ Diet composition (\%) } & \multicolumn{5}{c}{ Cultivar used in diet } \\
\cline { 2 - 5 } & 0 & Alfred & Soravi & Blandine \\
\hline Basal $^{1}$ & 96 & 48 & 48 & 48 \\
Faba bean Alfred & - & 48 & - & - \\
Faba bean Blandine & - & - & - & 48 \\
Faba bean Soravi & - & - & 48 & - \\
Mineral and vitamin mixture & \multicolumn{1}{c}{4} & 4 & 4 & 4 \\
Total & 100 & 100 & 100 & 100 \\
\hline
\end{tabular}

${ }^{1}$ Basal diet composition: Yellow maize, 67.77; soya bean meal (50\% protein), 32.0; DL-methionine 0.23 . (\%).

${ }^{2}$ Mineral and vitamin content $\left(\mathrm{kg}^{-1}\right.$ diet): vitamin $\mathrm{A}, 10000 \mathrm{IU}$; vitamin $\mathrm{D}_{3}, 1500 \mathrm{IU}$; vitamin $\mathrm{E}, 15 \mathrm{mg}$; niacin, $25 \mathrm{mg}$; vitamin $\mathrm{B}_{12}, 0.008 \mathrm{mg}$; calcium pantothenate, $8 \mathrm{mg}$; vitamin $\mathrm{K}_{3}, 5 \mathrm{mg}$; riboflavin, $4 \mathrm{mg}$; pyridoxine, $1 \mathrm{mg}$; folic acid, $1 \mathrm{mg}$; biotin, $0.2 \mathrm{mg}$; butylated hydroxytoluene, 125 $\mathrm{mg}$; choline chloride, $750 \mathrm{mg}$; Fe, $44 \mathrm{mg}$; $\mathrm{Cu}, 8.8 \mathrm{mg}$; Mn, $106 \mathrm{mg}$; Co, $0.3 \mathrm{mg}$; I, $1.2 \mathrm{mg}$; Se, $0.2 \mathrm{mg}$; $\mathrm{Zn}, 84 \mathrm{mg} ; \mathrm{NaCl}, 4 \mathrm{~g}$; dicalcium phosphate, $20 \mathrm{~g}$; calcium carbonate, $10 \mathrm{~g}$.

mineral and vitamin mixtures (MVM) at the $4 \%$ level (Table I). Each of the 4 experimental diets was then separated into 3 equal fractions which were either left untreated $(G)$, pelleted ( $P$ ) or pelleted and reground ( $P G$ ), giving the following three groups of diets (OG, A(Alfred) G, B (Blandine) G, $\mathrm{S}$ (Soravi) G), (OP, AP, BP, SP) and (OPG, APG, BPG, SPG).

The diets were steam-pelleted using a pellet mill (PSI-La Mecanicca type CLM 12). The temperature of the meal leaving the conditioner was $66-71^{\circ} \mathrm{C}$, these conditions being similar to those used in feed industry. The die thickness of the pellet mill was $25 \mathrm{~mm}$ and the pellet diameter was $2.5 \mathrm{~mm}$. The resulting pellets were cooled at room temperature before being ground with a laboratory Forplex hammermill (2-mm screen), in order to obtain a particle size similar to that of unpelleted diets (Diet group G) (Carré et al., 1987). Grinding caused only a slight increase in temperature $\left(2-3^{\circ} \mathrm{C}\right)$ compared with ambient conditions.

Particle-size determination was carried out on a duplicate 100 -g sample with a laboratory siever (Buhler DLU 300) using a set of woven-wire cloth sieves having a diameter of $26 \mathrm{~cm}$. The sieve openings were chosen according to Afnor specifications (NF X 11-501); the sieving time was $15 \mathrm{~min}$. The size of particles was reported in terms of geometric mean diameter and geometric standard deviation by weight (NF X 11-635).

The bioassay was carried out using 192 16-day-old chicks of similar weight. The birds were male Hubbard broiler chicks. Pairs of chicks were randomly assigned to 96 metal cages. Each cage was furnished with a feeder, a drinker and a plastic tray for the collection of excreta. 
A balance experiment was carried out from Day 17 to Day 24 on 16 birds (i.e., 8 cages) per diet using the total collection method described here. The birds were fed ad libitum during a 67 - $\mathrm{h}$ adaptation period, then fasted for $7 \mathrm{~h}$ before the 72-h balance period during which the birds were fed ad libitum for $65 \mathrm{~h}$ and then fasted for $7 \mathrm{~h}$. Excreta were collected during the balance period and stored at $-20^{\circ} \mathrm{C}$. Excreta were then freeze-dried, equilibrated at ambient temperature for 1 day, weighed, ground and kept in sealed plastic bags prior to analysis. Food intakes were corrected for variations in feed dry matter (DM) content observed between the beginning and the end of the balance feeding period.

Nitrogen was measured by Kjeldahl's method. Faecal nitrogen was measured on the faecal fraction separated from excreta by the procedure of Terpstra and de Hart (1974). Starch was measured in feed and excreta using the dimethylsulfoxide (DMSO) procedure (Boehringer Mannheim, 1980) as described by Carré et al. (1987). Gross energy of feed and excreta was measured with an adiabatic bomb calorimeter (Gallenkamp). The AMEn value of diets was calculated according to the procedure of Hill and Anderson (1958). The AMEn and digestibility values assigned to the field bean fractions were calculated by assuming additivity of the values assigned to field beans and basal fractions undergoing the same technical treatment.

The number of trypsin units inhibited per milligram dry matter (TUI $\mathrm{mg}^{-1}$ DM) was measured by two procedures (Valdebouze, 1977; American Oil Chemists' Society, 1975) and lipids according to Folch et al. (1957). Statistical analysis was performed by analysis of variance with comparison of means according to the Newman and Keuls test (Zivin and Bartko, 1976).

\section{RESULTS}

The proximate analysis of field beans showed little variation between the cultivars investigated (Tables II and III). However, Soravi seeds appeared to contain slightly less protein and starch. Temperatures during the pelleting process varied little between diets (Table IV). Particle sizes of ground (G), or pelleted and reground (PG), diets were similar. Cultivar type had no effect on particle size (Table V). The AMEn values of pelleted $(P)$ faba beans were greater than those of unpelleted $(\mathrm{G})$ beans $(P<0.001)$. The mean increase was $1.23 \mathrm{MJ} \mathrm{kg}^{-1}$ which represents an improvement of $12 \%$. Regrinding after pelleting slightly improved the AMEn values of faba beans ( $\mathrm{PG}$ compared with P), but this effect (1.2\% mean increase) was not significant (Table VI).

The AMEn values of the 3 faba bean cultivars seemed to be affected in different ways by pelleting, with effects increasing in the following order: Alfred, Soravi, Blandine. However, these differences in response to pelleting were not significant.

Differences in responses to pelleting became more clear when the digestibil- 


\section{TABLE II}

Chemical composition of faba beans ( $\%$ of DM)

\begin{tabular}{llll}
\hline \multirow{2}{*}{ Composition } & \multicolumn{2}{l}{ Cultivar } & \\
\cline { 2 - 4 } & Alfred & Soravi & Blandine \\
\hline Total protein $(\mathrm{N} \times 6.25)$ & 28.5 & 28.0 & 29.9 \\
Starch & 42.1 & 40.8 & 42.4 \\
Lipids & 1.7 & 1.8 & 1.8 \\
Ash & 3.4 & 3.8 & 3.5 \\
\hline
\end{tabular}

\section{TABLE III}

Trypsin inhibitor level in raw faba bean seeds and mash or pelleted diets (TVI units $\mathrm{mg}^{-\mathbf{1}}$ DM)

\section{Method}

$1 \quad 2$

Faba bean cultivars

$\begin{array}{lll}\text { Alfred (A) } & 2.8 & 2.9 \\ \text { Soravi (S) } & 2.1 & 3.1 \\ \text { Blandine (B) } & 2.9 & 2.8\end{array}$

Diet

$\begin{array}{lll}\text { A } & & \\ \quad \text { Mash } & 2.6 & 2.8 \\ \text { Pelleted } & 1.6 & 2.5 \\ \text { S } & & \\ \text { Mash } & 2.2 & 3.2 \\ \quad \text { Pelleted } & 2.1 & 2.9 \\ \text { B } & & \\ \text { Mash } & 2.3 & 3.2 \\ \text { Pelleted } & 1.6 & 2.4\end{array}$

Method 1: Valdebouze (1977).

Method 2: American Oil Chemists' Society (1975).

\section{TABLE IV}

Thermal conditions during pelleting

\begin{tabular}{lll}
\hline $\begin{array}{l}\text { Diet } \\
\text { group }\end{array}$ & \multicolumn{2}{l}{ Temperatures $\left({ }^{\circ} \mathrm{C}\right)$} \\
\cline { 2 - 3 } & Mash before the die & Pellets after the die \\
\hline OP, OPG & $66-70$ & $86-87$ \\
AP, APG & $66-67$ & 84 \\
SP, SPG & $71-72$ & 86 \\
BP, BPG & $70-71$ & $87-88$ \\
\hline
\end{tabular}

\footnotetext{
${ }^{1} \mathrm{O}$, control; $\mathrm{P}$, pelleted; $\mathrm{PG}$, reground pellets.
} 


\section{TABLE V}

Particle sizes of the diets (mean diameter in $\mu \mathrm{m} \pm$ s.d.)

\begin{tabular}{lllll}
\hline Diet type & \multicolumn{3}{l}{ Cultivar used in diet } \\
\cline { 2 - 5 } & 0 & Alfred & Soravi & Blandine \\
\hline Mash & $389 \pm 2.2$ & $382 \pm 2.5$ & $372 \pm 2.7$ & $387 \pm 2.4$ \\
Reground pellets & $404 \pm 1.9$ & $372 \pm 2.2$ & $406 \pm 2.1$ & $374 \pm 2.1$ \\
\hline
\end{tabular}

\section{TABLE VI}

Effects of processing on classical (AME) and nitrogen-corrected metabolisable energy (AMEn) values in 3 cultivars of faba beans $\left(\mathrm{MJ} \mathrm{kg}^{-1} \mathrm{DM}\right)$

\begin{tabular}{|c|c|c|c|c|}
\hline & \multicolumn{3}{|c|}{ Cultivar used in diet } & \multirow[t]{2}{*}{ Mean } \\
\hline & Alfred & Soravi & Blandine & \\
\hline \multicolumn{5}{|l|}{ AME } \\
\hline Mash diet & $11.16 \pm 0.18^{a}$ & $10.82 \pm 0.18^{\mathrm{a}}$ & $10.78 \pm 0.10^{\mathrm{a}}$ & 10.92 \\
\hline Pelleted diet & $12.09 \pm 0.13^{b}$ & $12.01 \pm 0.20^{\mathrm{b}}$ & $12.42 \pm 0.15^{b}$ & 12.17 \\
\hline $\begin{array}{l}\text { Pelleted reground } \\
\text { diet }\end{array}$ & $12.13 \pm 0.15^{\mathrm{b}}$ & $12.17 \pm 0.08^{\mathrm{b}}$ & $12.71 \pm 0.18^{b}$ & 12.34 \\
\hline \multicolumn{5}{|l|}{ AMEn } \\
\hline Mash diet & $10.64 \pm 0.16^{\mathrm{a}}$ & $10.30 \pm 0.16^{\mathrm{a}}$ & $10.17 \pm 0.09^{a}$ & 10.37 \\
\hline Pelleted diet & $11.50 \pm 0.13^{b}$ & $11.49 \pm 0.18^{b}$ & $11.80 \pm 0.14^{\mathrm{b}}$ & 11.60 \\
\hline $\begin{array}{l}\text { Pelleted reground } \\
\text { diet }\end{array}$ & $11.57 \pm 0.12^{b}$ & $11.61 \pm 0.06^{b}$ & $12.03 \pm 0.18^{b}$ & 11.74 \\
\hline
\end{tabular}

Values are means \pm s.e. Values followed by a different superscript are significantly different $(P<0.01)$.

ity of protein and starch in seeds from the 3 cultivars was investigated. Whatever the treatment considered, the highest protein digestibility values were always observed for the Blandine tannin-free cultivar $(P<0.05)$ (Table VII). The differences between protein digestibility values for Blandine seeds and those for other cultivar seeds were in the range of $13.2-15.7 \%$. The protein digestibility values for Alfred and Soravi beans were similar, the higher value found for Soravi not being significant (Table VII). Pelleting significantly increased $(P<0.05)$ protein digestibility values in the Alfred and Blandine cultivars but not in the Soravi cultivar. Regrinding after pelleting did not improve protein utilization in any cultivar.

The starch digestibility values for pelleted or unpelleted seeds were always lower in the Blandine cultivar than in the other two $(P<0.01)$, this difference being more pronounced in the case of unpelleted seeds (Table VIII). In each cultivar pelleting resulted in a strong improvement $(P<0.01)$ in starch digestibility values; this increase was in the range 7.9 (Alfred) $-14.6 \%$ (Blandine). 
TABLE VII

Effects of processing on apparent protein digestibility in 3 cultivars of faba beans (\%)

\begin{tabular}{lllll}
\hline \multirow{2}{*}{ Diet type } & \multicolumn{3}{l}{ Cultivar used in diet } \\
\cline { 2 - 5 } & Alfred (A) & Soravi (S) & Blandine (B) & Mean \\
\hline Mash & $66.9 \pm 1.3^{\mathrm{a}}$ & $69.4 \pm 1.9^{\mathrm{ab}}$ & $82.6 \pm 1.0^{\mathrm{c}}$ & 73.0 \\
Pelleted & $70.6 \pm 1.0^{\mathrm{b}}$ & $72.3 \pm 1.3^{\mathrm{b}}$ & $87.2 \pm 0.7^{\mathrm{d}}$ & 76.7 \\
Pelleted, reground & $70.6 \pm 0.8^{\mathrm{b}}$ & $72.1 \pm 0.8^{\mathrm{b}}$ & $86.5 \pm 0.8^{\mathrm{d}}$ & 76.4 \\
Mean & 69.4 & 71.3 & 85.4 & \\
\hline
\end{tabular}

Values are means \pm s.e. Values followed by a different superscript are significantly different $(P<0.05)$.

\section{TABLE VIII}

Effects of processing on starch digestibility in 3 cultivars of faba beans (\%)

\begin{tabular}{lllll}
\hline Diet type & \multicolumn{3}{l}{ Cultivar used in diet } & \\
\cline { 2 - 5 } & Alfred (A) & Soravi (S) & Blandine (B) & Mean \\
\hline Mash & $85.6 \pm 0.9^{\mathrm{b}}$ & $83.4 \pm 0.6^{\mathrm{b}}$ & $75.1 \pm 0.4^{\mathrm{a}}$ & 81.4 \\
Pelleted & $93.5 \pm 0.4^{\mathrm{d}}$ & $93.5 \pm 0.8^{\mathrm{d}}$ & $89.7 \pm 0.5^{\mathrm{c}}$ & 92.2 \\
Mean & 89.6 & 88.4 & 82.4 & \\
\hline
\end{tabular}

Values are means \pm s.e. Values followed by a different superscript are significantly different $(P<0.01)$.

\section{DISCUSSION}

The present results, showing higher protein digestiblity in tannin-free than in tannin-containing cultivars, are in agreement with previous studies carried out on young birds (Guillaume, 1978) and adult birds (Poulsen and Petersen, 1982 ), although these studies were different with respect to the levels of faba bean inclusion and the cultivars tested.

The protein digestibility values of untreated and heat-treated faba beans found in our assays were similar to those reported by Guillaume (1978). In both experiments, the heat treatment of diets (in the first case) and the heat treatment of faba beans (in the second case) induced only a slight increase in protein digestibility (4-9\%). However, in our results, protein utilisation in the tannin-containing cultivars was not enhanced by heat treatment as much as Guillaume (1978) and Marquardt and Ward (1979) have reported. However, these authors used autoclaving in the preparation of their diets whereas the present study employed pelleting.

Guillaume (1978) reported that starch digestibility was lower for untreated 
tannin-free field beans than for tannin-containing field beans. The beneficial effect of heat treatment on starch digestibility in tannin-free cultivars found in this study (Table VIII) has also been reported by Guillaume (1978). But in contrast with the results of the present study, Guillaume (1978) did not find such an effect in tannin-containing cultivars. This apparent discrepancy may be due to the higher level of field bean inclusion in Guillaume's experiment, or to differences in the methods of measurement of starch glucose. Concerning the latter point, Carré and Brillouet (1986) have shown that the measurement of glucose by the glucose-oxidase method used by Guillaume (1978) is not suitable for tannin-containing cultivars.

The low energy values of untreated seeds of tannin-containing and tanninfree cultivars of faba beans arise because young chicks are unable adequately to digest their starch and/or protein fraction; the differences in protein and starch digestibility between mash and pelleted diets explained $71-88 \%$ of seed AMEn increases. The mean AMEn value (10.37 $\mathrm{MJ} \mathrm{kg}^{-1} \mathrm{DM}$ ) of untreated faba beans, calculated for the 3 cultivars, was similar to values found by Edwards and Duthie $(1970,1972)$ for 11 samples of Throws M.S. field beans (10.50 $\left.\mathrm{MJ} \mathrm{kg}^{-1} \mathrm{DM}\right)$, and for 6 winter cultivars and 6 spring cultivars (10.92 $\mathrm{MJ} \mathrm{kg}{ }^{-1} \mathrm{DM}$ ).

As shown in the present experiment and in Guillaume's (1978) study, the energy value of seeds tends to be slightly lower in tannin-free cultivars than in tannin-containing cultivars.

In conclusion, it may be stated that pelleting of whole diets, an interesting treatment owing to its widespread utilization, can greatly improve (1.23 MJ $\mathrm{kg}^{-1}$ DM mean increase) the AMEn value of field beans. The utilization of tannin-free field beans appears particularly valuable in that their proteins are more digestible than those of tannin-containing seeds. However, no great improvement in field bean AMEn value can be expected from using tannin-free instead of tannin-containing seeds, as starch digestibility remains somewhat lower in the former, even after pelleting.

\section{ACKNOWLEDGMENTS}

The authors wish to thank the CIRIT Generalitat de Catalunya for his financial support.

\section{REFERENCES}

Afnor Standard NF X 11-501, Dec. 1970. Toiles métalliques et tôles perforées dans les tamis de contrôle. Dimension nominale des ouvertures. 4 pp.

Afnor Standards NF X 11-635 and 636, July 1985. Représentation des distributions granulométriques. Partie 1: Modèles de référence. $19 \mathrm{pp}$. Partie 2: Ajustement d'une courbe cumulative expérimentale à un modèle de référence. Cas du tamisage. $24 \mathrm{pp}$. 
American Oil Chemists' Society, 1975. Trypsin inhibitor activity. In: Official Tentative Methods of the AOCS, III. Tentative method, BA 12-75, AOCS Champaign IL, 2 pp.

Bhargava, K.K. and O'Neil, J.B., 1979. Raw and autoclaved faba beans (Vicia faba L.) as an alternate source of protein for broilers. Can. J. Anim. Sci., 59: 531-537.

Boehringer Mannheim, 1980. Methods of Enzymatic Food Analysis. Boehringer Mannheim, 6800 Mannheim 31, F.R.G.

Carré, B. and Brillouet, J.M., 1986. Yield and composition of cell wall residues isolated from various feedstuffs used for non-ruminant farm animals. J. Sci. Food Agric., 37: 341-351.

Carré, B., Escartin, R., Melcion, J.P., Champ, M., Roux, G. and Leclercq, B., 1987. Effect of pelleting and associations with maize or wheat on the nutritive value of smooth pea (Pisum sativum) seeds in adult cockerels. Br. Poult. Sci., 28: 219-229.

Edwards, D.G. and Duthie, I.F., 1970. Metabolizable energy values for broiler chicks of eleven samples of field beans (Vicia faba L.) harvested in 1968. J. Agric. Sci., Camb., 76: 257-259.

Edwards, D.G. and Duthie, I.F., 1972. A short note on the metabolizable energy values for broiler chicks of two varieties of field beans (Vicia faba L.) harvested in 1969. J. Agric. Sci., Camb., 79: $169-170$.

Edwards, D.G. and Duthie, I.F., 1973. Processing to improve the nutritive value of field beans. J. Sci. Food Agric., 24: 496-497.

Folch, J., Lees, M. and Sloane-Stanley, G.H., 1957. A simple method for the isolation and purification of total lipids from animal tissues. J. Biol. Chem., 226: 497-509.

Guillaume, J., 1974. Utilisation de la féverole ( Vicia faba L.) dans l'alimentation du poulet et de la poule pondeuse. In: Proceedings of the XVth World's Poultry Congress, New-Orleans, McGregor and Werner, Washington, pp. 616-617.

Guillaume, J., 1978. Digestibilité des protéines, de l'amidon et des lipides de deux types de féverole (Vicia faba L.) crue ou autoclavée chez le poussin. Arch. Gefluegelkd., 42: 179-182.

Guillaume, J. and Gomez, J., 1977. Effet des proanthocyanidines extractibles au méthanol absolu (PEMA) sur la digestibilité des protéines chez le poussin. Ann. Biol. Anim. Biochim. Biophys., 17: 549-552.

Hill, F.W. and Anderson, D.L., 1958. Comparison of metabolisable energy and productive energy determination with growing chicks. J. Nutr., 64: 587-603.

Huyghebaert, G. and de Groote, G., 1979. Les féveroles (Vicia faba) en tant que source protéique alternative dans les rations pour poulet de chair. 1. L'effet de divers traitements thermo-mécaniques. Rev. Agric., Brussels, 32: 1243-1255.

Huyghebaert, G. and de Groote, G., 1980. Les féveroles (Vicia faba) en tant que source protétique alternative dans les rations pour poulets de chair. 2. L'effet de la teneur en protéines et de la forme de l'aliment. Rev. Agric., Brussels, 33: 1281-1299.

Huyghebaert, G., Fontaine, G. and de Groote, G., 1979. Determination de la valeur alimentaire des pois (Pisum sativum) et des féveroles ( Vicia faba) au moyen d'essais de digestibilité avec des coqs adultes. Rev. Agric., Brussels, 32: 759-776.

McNab, J. and Wilson, B.J., 1974. Effects of micronising on the utilisation of field beans ( Vicia faba L.) by the young chick. J. Sci. Food Agric., 25: 395-400.

Marquardt, R.R. and Campbell, L.D., 1973. Raw and autoclaved faba beans in chick diets. Can. J. Anim. Sci., 53: 741-746.

Marquardt, R.R. and Campbell, L.D., 1974. Deficiency of methionine in raw and autoclaved faba beans in chick diets. Can. J. Anim. Sci., 54: 437-442.

Marquardt, R.R. and Ward, T., 1979. Chick performance as affected by autoclave treatment of tannin-containing and tannin-free cultivars of faba beans. Can. J. Anim. Sci., 59: 781-789.

Marquardt, R.R. and Ward, A.T., 1984. Chick performance as affected by autoclave treatment of tannin-containing and tannin-free faba beans. Fabis, 8: 23-25.

Marquardt, R.R., Campbell, L.D., Stothers, S.C. and McKirdy, J.A., 1974. Growth responses of 
chicks and rats fed diets containing four cultivars of raw or autoclaved faba beans. Can. J. Anim. Sci., 54: 177-182.

Marquardt, R.R., Campbell, L.D. and Ward, T., 1976. Studies with chicks on the growth depressing factor (s) in faba bean (Vicia faba L. var. minor). J. Nutr., 106: 275-284.

Poulsen, M.H. and Petersen, V.E., 1982. Digestibility of low tannin faba beans. Fabis Newsletter, 5: 35-36.

Shannon, D.W.F. and Clandinin, D.R., 1977. Effects of heat treatment on the nutritive value of faba beans (Vicia faba) for broiler chickens. Can. J. Anim. Sci., 57: 499-507.

Terpstra, K. and de Hart, N., 1974. The estimation of urinary nitrogen and fecal nitrogen in poultry excreta. Z. Tierphysiol. Tierernaehr. Futtermittelkd., 32: 306-320.

Valdebouze, $P$., 1977. Trypsin inhibiting and hemagglutinating activities in seeds of some legume species. In: Protein Quality from Leguminous Crops. November 1976, Dijon. Commission of the European Communities, Kinchberg, Luxembourg, EUR 5686 EN 1977: 87-98.

Zivin, J.A. and Bartko, J.J., 1976. Statistics for disinterested scientists. Life Sci., 18: 15-26. 